Perceptions of Electoral Fairness and Voter Turnout

\author{
Sarah Birch \\ Department of Government \\ University of Essex \\ Wivenhoe Park \\ Colchester CO4 3SQ \\ United Kingdom
}

Project on Electoral Malpractice in New and Semi-Democracies

http://www.essex.ac.uk/government/electoralmalpractice/

Working Paper No 3 


\begin{abstract}
:
Previous research has established a link between turnout and the extent to which voters are faced with a 'meaningful' partisan choice elections; this study extends the logic of this argument to perceptions of the 'meaningfulness' of electoral conduct. It hypothesizes that perceptions of electoral integrity are positively related to turnout. The empirical analysis to test this hypothesis is based on aggregate-level data from 31 countries, combined with survey results from Module 1 of the Comparative Study of Electoral Systems survey project, which includes new and established democracies. Multilevel modeling is employed to control for a variety of individualand election-level variables that have been found in previous research to influence turnout. The results of the analysis show that perceptions of electoral integrity are indeed positively associated with propensity to vote, and there is limited evidence to suggest that the relationship is stronger in established than in new democracies.
\end{abstract}




\section{Perceptions of Electoral Fairness and Voter Turnout*}

The comparative study of voter turnout has exhibited an increasing focus in recent years on citizens' perceptions of the competitive context in which elections take place (e.g. Blais 2000; Franklin1996; 2002; 2004; Jackman 1987; Jackman and Miller 1995; Milner 2002; Norris 2002; 2004). Most such research has conceptualized the competitiveness of elections in terms of the choices on offer, the decisiveness of the contest, and citizen perceptions of the legitimacy of political institutions. This study extends that line of enquiry by examining another aspect of electoral competitiveness: the degree to which an election is perceived as being a fair contest.

Electoral integrity is a topic that has until recently received scant attention from comparative political scientists. However, a growing body of literature, building on the insights of those involved in the field of electoral assistance and observation, has stressed the importance of confidence in electoral processes in new and emerging democracies (Birch 2007; 2008; Elklit 1999; Elklit and Reynolds 2002; 2005; Goodwin-Gill 1998, 56-8; Hartlyn and McCoy 2006; Lehoucq 2003, 252; Lyons 2004; Mozaffar 2002; Mozaffar and Schedler 2002; Schedler 2002a; 2002b; 2006). As Fabrice Lehoucq argues, “[electoral] fraud undermines [citizens'] ability to constrain the actions of state officials. [...] to the extent that public officials can corrupt the electoral process, they are less accountable to the electorate" (Lehoucq 2002, 35). Lack of trust in electoral institutions can therefore erode citizens' perceptions of the legitimacy of other political institutions, it can dent international legitimacy (with possible knock-on effects for donor aid), and in some cases it can even spark civil unrest.

The purpose of this paper is to explore another possible consequence of perceptions of electoral misconduct: its impact on voter turnout. In so doing, the paper sets out to integrate

\footnotetext{
* I am grateful to the University of Essex and to the British Academy (Grant SG-46162) for
} 
recent work on electoral processes in emergent democracies and semi-democratic countries with the traditional concerns of electoral behaviorists by suggesting that in democracies old and new, perceptions of the electoral process are part of the broader context of political perceptions that structure the choice of whether or not to vote. The principal argument put forward here is that confidence in electoral conduct has an important and previously understudied impact on the likelihood that voters will go to the polls: when voters are confident that an election will be free and fair, they are more likely to vote, all else being equal, than is the case when they have reservations about the ability (or willingness) of those conducting the election to maintain democratic standards of electoral integrity. This hypothesis is tested and confirmed in a multilevel analysis of 31 elections held between 1996 and 2002 in established and new democracies.

\section{Evaluations of Electoral Integrity and the Likelihood of Voting}

Political scientists have long been aware of the association between various measures of regime legitimacy and voter turnout (Clarke and Alcock 1989; Finkel 1985; Norris 2002, 86-98; 2004, 158-9; Powell 1986; Karp and Banducci, 2008), but there has been virtually no systematic consideration of what is arguably the most relevant aspect of institutional legitimacy: confidence in the electoral process itself. Low levels of popular confidence in the conduct of elections can be expected to shape citizens' approach to the electoral choice situation in a variety of ways. Specifically, there are several reasons for believing that low quality opportunities for participation might translate into lower quantitative levels of turnout. If voters fear that polls are corrupt, they have less incentive to bother casting a vote; participating in a process in which they

material support for this project. 
do not have confidence will be less attractive, and they may well perceive the outcome of the election to be a foregone conclusion. There is some anecdotal and survey evidence to suggest that perceptions of the quality of elections are associated with voter turnout in a number of African (Bratton and van de Walle 1997, 206-10; Bratton 1998) and Latin American (McCann and Dominguez 1998; Zovatto 2003) states. ${ }^{1}$ Yet this relationship has yet to be systematically examined in a cross-national context.

Following Przeworski (1988) and Mozaffar and Schedler (2002), procedural certainty - in the form of effective, reliable and unbiased electoral institutions - is a necessary requirement for the uncertainty in outcomes that defines democracy. It follows that the establishment and maintenance of electoral integrity involves guaranteeing the indeterminacy election results by safeguarding the reliability of electoral institutions. Violation of integrity occurs when the indeterminacy of the outcome is compromised by the politically motivated application of electoral rules. When this happens, and there is widespread public awareness that it has happened, voters cannot be sure that their vote will be fairly counted, and in some cases they may even be convinced that their vote will not be fairly counted: "as long as electoral governance artificially reduces electoral uncertainty [...] electoral processes are unlikely to be perceived as fully democratic, or, by implication, fully legitimate" (Mozaffar and Schedler 2002, 11).

It can be assumed that if electoral integrity has an impact on voter turnout, this will be largely mediated by perceptions of the electoral process, though electoral fraud and related forms of malpractice can also manifest themselves through the direct manipulation of participation. Up to now I have assumed, together with the vast majority of those who study voting behavior, that voters vote on the basis of their genuine preferences over electoral options, and that those preferences reflect their evaluations of the impact of the electoral outcomes on the provision of public goods. But various forms of 'undue influence' may increase turnout; if people are bribed 
to go to the polls or mobilized through clientelist relations, or alternatively if they are threatened with force or loss of financial security should they fail to turn out to vote, then electoral participation can be expected to be artificially high. It is well known that those who seek to 'steal' elections often avoid outright fraud and violations of the integrity of the vote act, and focus instead on altering the basis on which voters make their choices (see Lehoucq 2003 and Schaffer, 2007a, 2007b for overviews of this phenomenon). Voters may be provided with particularistic rewards for casting a vote for a certain option, and they must be able to demonstrate that they have voted in order to be able to claim their reward. In other words, manipulative practices that reduce the credibility of the election (and thereby reduce the incentive for voters to participate) may simultaneously alter the material costs and benefits of participation, thereby increasing such incentives. ${ }^{2}$

We may therefore observe higher turnout in manipulated elections, but it is unclear that this will dramatically alter the relationship between perceptions of electoral integrity and propensity to vote. This is first because it is typically the case that only the votes of a relatively restricted proportion of the electorate can and will be 'bought' in any given election, due to the logistic and material costs of organizing mass vote-buying (Lehoucq and Molina 2002; Lehoucq 2003; Molina and Lehoucq 1999; Schaffer 2005, 2007b; Schaffer and Schedler, 2007: 19), and second because those who allow their votes to be bought may be less likely to perceive (or admit) that the election was unfair, in that they have actively colluded with the violation of fairness. ${ }^{3}$

All in all, there are reasons to believe that actual electoral misconduct will in some cases increase rates of electoral participation, but that perceptions of malpractice will have the countervailing effect of decreasing it. Which of these forces is stronger is of course an empirical question, that will be addressed in the sections to follow, but for the reasons elaborated above, it 
is likely that the effect of unfavorable evaluations of electoral integrity will be greater than that of vote-buying in all but elections of the poorest quality.

In rational choice terms, the main insight offered by this analysis is that if vote calculus models (as developed by Riker and Ordeshook (1968), Ferejohn and Fiorina (1974), Aldrich (1993), Blais (2000) and others) are to be extended to a wider variety of electoral contexts, they must take into consideration rewards and punishments as well as the perceived likelihood that one's vote will be fairly counted, accurately included in the vote tabulation, and that the tabulated votes will be accurately reported - in other words, the perceived likelihood that the election will be conducted fairly. If voters perceive that their vote will not offer them an opportunity to contribute to the selection of leaders, they can be expected to discount the utility of the outcome when deciding whether it is worth their while to vote. Furthermore, considerations of reliability are logically anterior to considerations of decisiveness: it only makes sense for a voter to engage in calculations of outcome utility and decisiveness once they have established that there is sufficient likelihood that their vote will be reliably processed. This suggests that the costs of deciding whether to vote will in certain circumstances reduce to an estimation of the probability that the election will be conducted fairly; if this probability is very low, it will be rational for the voter to stay at home, regardless of how much they care about the outcome, and regardless of how decisive they think their vote might be, unless, of course, particularistic rewards are sufficient to outweigh the net costs of going to the polls.

It remains in this section to identify those individual- and polity-level variables that have been found in previous studies to be significantly related to turnout, and which therefore need to be included in the empirical analysis as controls.

At the individual level, the variables that can be expected to impact on propensity to vote can be grouped according to the various theoretical paradigms that have been employed to model 
electoral participation: resource theories, mobilization theories, and cognitive involvement theories.

Resource theories predict that factors such as age, education level, and socio-economic status ought to be positively associated with turnout; older, better educated members of the electorate and the more affluent in a country have been found to vote with greatest frequency (Blais 2000, 53; Clarke et al. 2004, 237-61; Dalton 1996, 57-8; Franklin 1996; 2002; 2004; Norris 2002, 86-96; 2004, 158-9; Powell 1986; Verba et al. 1978). Early studies suggested that men were more frequent voters than women (Powell 1986; Verba et al. 1978), while some more recent analyses show that in many democracies women are now more likely than men to vote (Blais 2000, 53; Norris 2002, 86-91). Mobilization models have demonstrated that an individual's degree of integration into and mobilization by civil society organizations such as unions, religious groups and political parties increases the likelihood that they will exercise their franchise (Blais 2000, 53; Campbell et al. 1960, 99-100; Clarke et al. 2004, 237-61; Crewe 1981; Dalton 1996, 57-8; Franklin 1996; 2002; Gray and Caul 2000; Jackman 1986; Norris 2002, 8697; 2004,158-9; Pérez-Liñán 2001; Powell 1980; 1986; Rosenstone and Hansen 1993; Uhlaner 1989; Verba et al. 1978; Verba et al. 1995; Vowles 2002).

Finally, studies assessing cognitive involvement have found that factors such as political interest and political knowledge make people more likely to vote, as do variables related to legitimacy and regime support, such as external efficacy and satisfaction with democracy (Clarke et al. 2004, 237-61; Finkel 1985; Franklin 1996; 2002; Lassen 2005; Milner 2002, chs. 2 and 3; Norris 2002, 86-98; 2004, 158-9; Powell 1986; Karp and Banducci, 2008). It is worth pausing to consider the extent to which perceptions of electoral fairness are truly distinct from other measures of legitimacy. On the one hand, this variable is perhaps the most direct and relevant measure of legitimacy in the electoral context. On the other hand, if it is simply a proxy for other 
variables that have long been known to be associated with turnout, then this lessens its conceptual interest to students of electoral participation. As will be demonstrated below, confidence in electoral conduct is distinct from other measures of legitimacy and regime support, and it exhibits an independent influence on voter turnout.

At the aggregate level, institutional, contextual, and socio-political factors have been shown in numerous studies to be linked to rates of electoral participation. As far as electoral institutions are concerned, elections conducted under proportional representation have been shown to have higher levels of turnout than those conducted under other electoral systems (Blais 2000, 28-31; 2006, 115-6; Blais and Carty 1990; Blais and Dobrzynska 1998; Crewe 1981; Franklin 1996; 2002; Geys 2006; Jackman 1987; Jackman and Miller 1995; Karp and Banducci 2008; Milner 2002, ch. 5; Norris 2002, 64-66; 2004, 158-62; Powell 1980; 1986). Not surprisingly, countries with compulsory voting have generally been found to have higher turnout levels than those where voting is voluntary, all else being equal (Blais 2000, 29-31; 2006, 113; Blais and Carty 1990; Blais and Dobrzynska 1998; Crewe 1981; Franklin 1996; 1999; 2002; 2004, 133-37; Jackman 1987; Jackman and Miller 1995; Norris 2004, 158-70; Pérez-Liñán 2001; Powell 1980; 1982).Voting facilities, including weekend voting, postal and other forms of advance voting, and voting in special polling places, have also been demonstrated in some studies to influence turnout, though these effects have generally been found to be weak (Crewe 1981; Franklin 1996; 2002; 2004, 148; Norris 2002, 77-80; 2004, 173); moreover, as Franklin suggests (2004, 148), they may be partly endogenous, in that states with particularly low levels of electoral participation may introduce vote-facilitating mechanisms as a means of boosting turnout.

A second set of election-level factors that appear to influence aggregate turnout levels are those relating to the political context in which the race is conducted. Following the logic of rational choice theory outlined above, closely fought elections (generally operationalized in terms 
of the margin of victory of the winner) have been shown by a number of studies to yield higher aggregate-level turnout (Blais 2000, 31; 2006, 119; Blais and Carty 1990; Blais and Dobrzynska 1998; Crewe 1981; Franklin 2002; 2004, 133-5; Geys 2006; Powell 1980). The decisiveness or salience of the election in question - the degree to which the institution elected can control policy-making - has also been found to be associated with higher turnout. Legislative elections in states with bicameral parliaments and/or directly-elected presidents have been shown, on average, to have lower levels of electoral participation in legislative elections than states with unicameral parliamentary systems (Blais 2000: 28-31; Blais and Dobrzynska 1998; Franklin 1996; 2002; 2004, 133-5; Jackman 1987; Jackman and Miller 1995; Norris 2004, 158-64). An additional political context variable known to influence turnout at the aggregate level is the length of time since the previous election (or the frequency of elections); when people are called out to vote more often, they are less likely to participate in any given election (Franklin 2002; 2004, 133-5; Norris 2002, 65-9; 2004, 158-65).

Finally, several socio-political attributes of polities are known to be associated with aggregate levels of electoral participation, including level of economic development (citizens in more developed states vote with greater frequency; Blais 2000, 29; Blais and Dobrzynska 1998; Crewe 1981; IDEA 2002; Norris 2002, 44-5; 2004 160; Powell 1980; 1982), size of the population (smaller states tend to have higher turnout levels; Blais 2000, 29; Blais and Carty 1990; Blais and Dobrzynska 1998; Franklin 2002; Geys 2006), and experience of democracy (established democracies have higher turnout levels on average than other states; IDEA 2002, 86; Norris 2002, 46-8).

In sum, a variety of political, institutional, and socio-economic variables operating at both the individual and the aggregate levels can be expected to predict propensity to vote and will therefore be included as control variables in the analysis to follow. 


\section{Data and Methods}

The majority of the indicators used in this analysis are drawn from Module 1 of the Comparative Study of Electoral Systems (CSES). This project is a major collaborative endeavor that involves the inclusion of a series of common electoral survey questions in national election studies so as to enable cross-national comparisons. The Module 1 database includes the pooled results from the relevant sections of 39 election surveys conducted in 33 countries between 1996 and 2002, as well as election- and country-level variables on political institutions. Usable data for they key variables under consideration were available for 31 cases (see Table 1). ${ }^{4}$ CSES data on these 31 elections were supplemented by aggregate-level data, detailed below.

The dependent variable employed here consists of responses to the standard survey items on turnout. The main independent variable in this analysis, perceptions of electoral fairness, was constructed on the basis of the following survey item: "In some countries, people believe their elections are conducted fairly. In other countries, people believe that their elections are conducted unfairly. Thinking of the last election in [country], where would you place it on this scale of one to five where ONE means that the last election was conducted fairly and FIVE means that the last election was conducted unfairly?”

This item might not, on the face of it, appear to be a very promising indicator for predicting electoral participation. The question was asked after the election was over, after respondents had voted (or not voted) and after they had had the opportunity to evaluate the electoral process from start to finish. Their answer to this question may thus partly reflect their experience on or following election day. If this were the case, it would mean that evaluations of

electoral fairness were a consequence, not a cause, of turnout. ${ }^{5}$ This possibility is discussed and tested at greater length below, but there are several reasons to believe that confidence in the 
electoral process reflects attitudes and evaluations that have largely crystallized at the time of the election and are unlikely to change significantly thereafter (save in exceptional cases). Most voters (even in new democracies) have experienced a number of elections in their country, and it is unlikely that their views of the fairness or otherwise of the electoral process will be significantly altered by a single electoral event. Furthermore, the factors which make an election 'fair' or 'unfair', such as the institutional rules and bodies governing the election, the admission or exclusion of candidates, and the campaign, mostly take place before election day itself. Finally, if perceptions of the electoral process are altered following the election by objective events and reports on the elections in the media, these factors will most likely change the perceptions of all respondents, regardless of whether or not they voted.

The act of voting itself can be expected to affect perceptions of electoral integrity in one of two ways: by increasing the respondent's stake in the election, and by providing him or her with additional information about the electoral process. In the first case, the concern raised is that those whose favored party or candidate loses the election may have a less sanguine assessment of electoral conduct. Indeed, Chris Anderson and his colleagues find that 'losers' in the electoral process are less likely to evaluate the electoral process favorably, even controlling for a variety of other factors (Anderson et al. 2005, 144-59). ${ }^{6}$ In the multivariate analyses reported below, this 'sour grapes' interpretation of electoral confidence is controlled for by introducing a variable designating whether or not the respondent reported identifying with the winning party (or the winning candidate's party). It is worth noting at this point that the mean fairness rating among 'losers' (those identifying with a losing party) was 1.95 , compared to 1.92 among 'winners' and non-identifiers - a very small difference. This difference is significant at the .001 level, yet this is not surprising in a sample of nearly 40,000. Moreover, aggregate-level analyses reveal that 'losers' are significantly more likely to give an election a worse rating in only six of the countries 
included in the dataset (the Czech Republic, Hungary, Israel, Mexico, Portugal, and Spain). These findings suggest that 'sour grapes' had little potential to mediate impacts on turnout, a conclusion that will be confirmed in multivariate analysis.

An alternative conception of 'stake' in an election might be formulated with reference to cognitive dissonance theory (Festinger 1957). It may be that, having participated in an event, voters are more likely to express a positive evaluation of that event, so as to justify their participation. Though studies of the role of voting on other measures of external efficacy have found limited evidence for such an effect (Clarke and Alcock 1989; Finkel 1985), this hypothesis is nevertheless worth considering.

The former concern - that the act of voting may itself have conditioned views of the electoral process - is trickier to address, but these are several reasons to believe that this effect will be minimal. Voters have multiple sources of information about the fairness of an election, from press reports to word-of-mouth, and the observed performance of candidates and election officials both before and after the election. And though the fact of voting at a polling station that appears to be orderly, efficient, and free of outright fraud may tend to improve voters' perceptions of the integrity of the electoral process, even the most naïve of voters can be expected to be aware that they have 'observed' the electoral process at their polling station for a very small proportion of the time it was in operation, and that their sample of one polling place constitutes a poor basis on which to generalize to the electoral process as a whole. Finally, voting may decrease confidence in the election as well as increase it. If voters have to wait a long time to vote, or if conditions in the polling station are chaotic, they may leave feeling that the election was less well-conducted than they had thought, so we can not necessarily assume that voting can in all cases be expected to increase electoral confidence. We can thus be reasonably sure that the question about electoral fairness taps a general view of the electoral process that is not strongly 
influenced by the vote act itself. We shall nevertheless return to the question of endogeneity in the following section.

Unfortunately, it was not possible to include a direct measure of particularistic incentives, due to the lack of suitable comparative data. In the context of the present analysis, socioeconomic status will serve as one proxy, given that particularistic rewards are known to be particularly attractive to the poor (Callahan 2000; Desposato, 2007; Figueroa and Sives 2002; Hicken, 2007; Schaffer 2002; 2005; Shaffer 2007b; Stokes, 2007). If mobilizing vote-buying is at work, we should expect the poor to vote with greater frequency than the rich, all else being equal, which is contrary to the impact of wealth found in previous studies. A second proxy is the institutional variable of campaign expenditure limits. Though such limits are not always well enforced, we might expect them to have at least a weak downward pressure on vote-buying, in as much as they set a cap on overall spending. Use of proxies is not an entirely satisfactory solution, yet until better datasets are available on phenomena such as these, there is little alternative. Given that the main aim of this paper is to test the impact of perceptions of electoral fairness on voter turnout, this drawback is not as serious as it might seem, though a fuller integration of electoral integrity issues into the study of electoral participation would ideally employ a better and more direct measure of particularistic incentives.

Two variables found in previous studies to be associated with turnout were excluded from the analysis due to lack of suitable data. Compulsory voting was not included because there was no true variation in the dataset used here - none of the states in question employs enforced compulsory voting. Voting methods were also left out, though for different reasons. An index of vote facilitating mechanisms was constructed on the basis of the available data; one point was awarded a state if it held elections over two days, one point if elections were conducted on a rest day, and one point if postal voting was allowed (half a point if it was allowed only for certain 
categories of people). ${ }^{7}$ The three scores were then summed to create a variable that ranged from 0 to 3. Unfortunately, reliable data were available for only about two-thirds of the elections in the dataset, such that inclusion of this variable would have resulted in too few macro-level cases to make meaningful multilevel analysis possible. Moreover, bivariate correlations between this index and aggregate-level turnout - as well as between each of the components parts of the index and turnout - did not prove to be statistically significant, suggesting that their exclusion from multivariate analysis will not result in serious misspecification.

Details of the construction of the remaining control variables are included in the Appendix. The main method employed to test the hypotheses elaborated above is multilevel modeling. This technique allows inclusion of the two types of control variables described above, as well as cross-level interactions (see Steenbergen and Jones 2002). ${ }^{8}$

\section{Results}

Preliminary bivariate analysis at both individual and aggregate levels supports the hypothesis that electoral confidence fosters turnout. At the individual level, those survey respondents who reported having voted rated the fairness of the election in which they had participated 1.89 on average (recall that this scale ranges from 1 to 5 , with 1 representing the view that 'the last election was conducted fairly' and 5 reflecting the opinion that 'the last election was conducted unfairly'), while the average score for those who claimed not to have voted was 2.22 , a difference significant at the .001 level. At the aggregate level, there is a correlation of .367 (significant at the .05 level) between the proportion of survey respondents who expressed full confidence in the electoral process (responded ' 1 ' to the question cited above) and official turnout (as a proportion of the voting-age population). The correlation between the proportion expressing broad confidence (those who answered either ' 1 ' or ' 2 ' to the electoral fairness question) and aggregate 
turnout is .265 , though this coefficient fails to reach statistical significance (see Table 1). These findings provide prima facia evidence that confidence in the electoral process leads to increased levels of voter turnout.

But the real test of this relationship must carried out in a multivariate context. We start with a random intercepts logit model with individual-level variables only (Model 1 in Table 2). This model shows that perceptions of electoral fairness have a strong and highly significant impact on willingness to cast a ballot. The control variables are virtually all significant and in the expected direction, but even controlling for the factors that have been found repeatedly in previous studies to affect turnout, perceptions of fairness still stands out as a strong predictor. ${ }^{9}$ The positive coefficient for income suggests that the mobilizing impact of vote-buying among the poor is outweighed in this dataset by the well-known tendency in democracies for those better off to vote with greater frequency, though it should be noted that this variable is less significant than most others in the model, suggesting that the countervailing influence of vote-buying (which it was not possible to test directly) may have also been at play.

It is also clear that confidence in elections has an impact independent of other legitimacy variables: though there is a fairly strong bivariate association between satisfaction with democracy and perceptions of electoral fairness (Kendall's tau-b $=.274$, significant at .004 ) and external efficacy (Kendall's tau-b = .089, significant at .004 ), this model supports the hypothesis that evaluations of electoral integrity have an impact independent of overall evaluations of the democratic system.

It is also noteworthy that party identification with a loser does not prove significant, nor does an interaction term between party identification with a loser and perceptions of electoral fairness, designed to test whether the effect of such perceptions may have been conditioned by support for an unsuccessful party (the 'sour grapes' hypothesis). Finally, as we know from 
numerous previous studies, there is considerable variation in propensity to vote among countries (as indicated by the highly significant variance term for election intercepts), even controlling for individual-level factors.

-- Table 2 about here --

Unfortunately, a number of the CSES surveys did not ask questions on union membership, religion, or political information, and because different questions were omitted in different surveys, Model 1 only includes 22 elections. ${ }^{10}$ In order to retain enough macro-level cases for the introduction of election-level controls to be possible, those variables with significant amounts of missing data, as well as those insignificant in Model 1, were removed in Model $2 .{ }^{11}$ In Model 2, perceptions of electoral fairness were allowed to vary over elections (in other words, this is a fully-random model), and a range of election-level variables know to influence aggregate turnout were added. The results reported here are largely in agreement with expectations, though many of the variables fail to reach conventional levels of significance, presumably due to the relatively small number of macro-level cases included. ${ }^{12}$

Somewhat unexpectedly, the margin of victory (employed as a measure of the closeness of the race) is associated with increased turnout in this dataset (with no evidence of a cross-level interaction between margin of victory and perceptions of electoral fairness). Examination of the data reveal that Belarus is a distinct outlier on this variable, in that the margin of victory in the Belarusian election included in this dataset was 60 percent, whereas the next highest figure was 26.3 percent (Taiwan). When Belarus is removed from the dataset, this coefficient is no longer significant, suggesting that it is the relatively high level of turnout among Belarusian voters that accounts for this anomalous finding.

The most noteworthy aspect of this model from the point of view of the present analysis is the fact that the electoral confidence variable remains highly significant, and its coefficient has 
barely changed from Model 1. All in all, the relationship between perceptions of electoral fairness and propensity to vote appears to hold in across a variety of institutional and political settings, lending confidence to the robustness of the results presented here.

The final stage in the analysis was to test for cross-level interactions between perceptions of electoral fairness and the election-level variables. In other words, we are interested to know whether the impact of perceptions of electoral fairness on turnout is conditional on polity-level factors such as institutional design or aspects of electoral competition. The only such variable to come close to reaching conventional levels of statistical significance was that between perceptions of electoral fairness and the dummy variable designating established democracies (see Model 3). ${ }^{13}$ The coefficient for this model is positive and significant at .117, which provides limited evidence that the impact of perceptions of electoral fairness on turnout is actually stronger in established democracies than it is in newly- and semi-democratic states. This could be due to the fact that citizens in established democracies hold their elections to higher standards, or it could be because the impact of electoral confidence is attenuated in some newer democracies by vote-buying or other phenomena that increase turnout under conditions of poor electoral conduct. The latter possibility suggests that there may be a threshold of electoral confidence below which turnout is motivated by other factors. This possibility remains speculative, however, and provides grounds for future research.

A final consideration is the possibility of endogeneity, mentioned above. This is an issue that arises in the context of many attitudinal variables that are highly proximate to the voting decision, such as party identification, political interest/information, and efficacy: behavior (voting) can be expected to reinforce pre-existing attitudes, at the same time as being a consequence of them (Anderson and LoTempio 2002; Anderson et al. 2005, 26-9, 193-4; Finkel 1985; 1987; Ginsberg and Weissberg 1978; Lassen 2005; Nadeau and Blais 1993). The same 
could be true of perceptions of electoral fairness. Unfortunately the question on electoral fairness was asked only in the first module of the CSES, and it is always difficult to disentangle causal flows in cross-sectional data. Moreover, statistical 'fixes' typically employed with this type of data such as instrumental variables are precluded in the present instance by the lack of efficient and exogenous instruments for perceptions of electoral fairness (the only indicators with which this variable is highly correlated are those such as satisfaction with democracy that cannot be assumed to be exogenous either).

Fortunately, for our purposes, the British Panel Study of 1997-2001 re-interviewed those interviewed as part of the CSES module again following the 2001 general election, thus making it possible to ascertain whether perceptions of electoral fairness in 1997 impacted on vote decision in 2001, as the argument advanced here would lead one to expect. The UK is a useful case on which to test this hypothesis, as there is little reason to expect that the objective or perceived quality of elections will have changed between the two elections.

-- Table 3 about here --

The models in Table 3 provide approximate replications of the individual-level model in Table 2, but using British data panel from 1997 and 2001 (it was not possible to include exactly the same variables as those employed in the cross-national analysis, due to reduced variable availability for the 2001 British survey). ${ }^{14}$ As expected, perceptions of electoral fairness in 1997 had a strong impact on turnout four years later in 2001. Moreover, the impact of perceptions in electoral fairness in 1997 on turnout in 2001 is greater than its effect on turnout in 1997. This is what the argument advanced here would suggest: voters perceptions of the fairness of an election can only be fully formed after the entire electoral process is complete. This perception is therefore likely to have its greatest impact in the subsequent election, which is precisely what we observe in the British data. Thus, while these findings do not allow us entirely to discount the 
potential impact of voting on perceptions of electoral fairness, they do provide strong evidence to support the main hypothesis of this paper: that perceptions of electoral fairness influence whether or not people turn out to vote.

\section{Conclusion}

Most previous research on the link between evaluations of political legitimacy and electoral participation has examined the 'who' and the 'what' but ignored the 'how'. Citizens have been asked to evaluate the integrity, competence and responsiveness of elected officials as well as the

efficiency and fairness of the political system's outputs, and their answers to these questions have been linked to propensity to engage in electoral and other forms of political participation. But research in this vein has largely neglected the link between voter turnout and what is arguably the most obvious and most crucial legitimacy evaluation that prospective voters make: how well the election in question is likely to be conducted. This paper has sought to remedy this gap in the comparative literature, and in so doing it has found that citizens who perceive elections to be fair are more likely to vote than those who have reservations about the conduct of electoral contests. This relationship has been shown to be robust even when other individual- and election-level variables are controlled, and the impact of perceptions of electoral fairness has been demonstrated to be distinct from that of related factors such as political efficacy and satisfaction with democracy. Moreover, there is limited evidence to suggest that the effect in question may actually be stronger in established democracies than in new and emerging democratic systems.

How strong is this effect? The substantive impact of broad confidence in the electoral process was calculated from Model 3, holding continuous variables at their means and nominal and ordinal variables at their modes. This calculations shows that having confidence in the electoral process is associated with an increased probability of voting of 4.846 percent. Though 
this figure is by no means huge, it does represent a substantial impact, suggesting that confidence in the electoral process is one of the more important factors conditioning propensity to participate in electoral politics.

This analysis also has consequences for our understanding of democratic quality. Confidence-related abstention can have a variety of nefarious consequences for democracy. If democrats choose to exit from electoral politics in reaction to perceived flaws in electoral processes, the result may be a downward spiral in democratic performance and legitimacy. As Fabrice Lehoucq argues, "If rates of voter participation fall, then fabricating a handful of votes may be sufficient to retain power, a fact that opposition or regional parties may exploit as elections become more competitive" (2003, 253). Similarly, McCann and Dominguez show that abstention due to perceptions of fraud helped the PRI stay in power in Mexico $(1998,498)$. It is perhaps not surprising that Bingham Powell found higher levels of turnout to be associated with a lower incidence of riots and protests (1982, ch. 10).

The results presented here thus have potential implications for policy. Falling turnout has been of concern in recent years, not just among political scientists, but among political actors as well. The findings of this paper suggest that if states want to improve turnout, one measure they could take would be to increase confidence in the electoral process. The most obvious means of achieving this end is to improve the conduct of elections. States that are actively engaged in cleaning up their elections also need to make strenuous efforts in the area of voter education, in order to inform their publics of their activities and to convince them that the quality of elections has in fact improved. Moreover, the evidence presented here suggests that proposals in some countries to expand the use of postal, electronic and absent voting in order to increase turnout may actually have the opposite effect, if they simultaneously decrease confidence in the electoral 
process. This might be the case, for example, if such provisions were abused and stories of abuse were widely publicised.

Elections are the building blocks of democracy; it follows that electoral integrity is a precondition for meaningful democratic competition at all levels. In as much as poor evaluations of the fairness of elections keeps citizens away from the polls, democratic legitimacy and performance will be compromised. It is for this reason that the study of electoral confidence is key to understanding the role of elections in the ever-widening world of competitive politics. This paper has considered the importance of perceptions of electoral integrity for turnout, but similar analyses could profitably be extended to a range of aspects of political behavior, including vote choice and other forms of political participation. Undertaking such a task would provide a muchneeded integration of the study of electoral manipulation and malpractice with the traditional concerns of behavioralists. 


\section{References}

Akhter, Muhammad Yeahia. 2001. Electoral Corruption in Bangladesh. Aldershot: Ashgate.

Anderson, Christopher J., André Blais, Shaun Bowler, Todd Donovan, and Ola Listhaug. 2005. Losers' Consent: Elections and Democratic Legitimacy. Oxford: Oxford University Press.

Anderson, Christopher J., and Christine A. Guillory, 1997. "Political Institutions and Satisfaction with Democracy: A Cross-National Analysis of Consensus and Majoritarian Systems.” American Political Science Review 91(1):66-81.

Anderson, Christopher J., and Andrew J. LoTempio. 2002. "Winning, Losing and Political Trust in America.” British Journal of Political Science 32(2):335-51.

Anderson, Christopher J., and Silvia M. Mendes. 2006. 'Learning to Lose: Election Outcomes, Democratic Experience and Political Protest Potential.’British Journal of Political Science 36(1):91-111.

Aldrich, John H. 1993. "Rational Choice and Turnout.” American Journal of Political Science 37(1):246-78.

Argersinger, Peter H. 1985/6. "New Perspectives on Election Fraud in the Gilded Age." Political Science Quarterly 100(4):669-87.

Banducci, Susan A., and Jeffrey Karp. 2003. "How Elections Change the Way Citizens View the Political System: Campaigns, Media Effects and Electoral Outcomes in Comparative Perspective." British Journal of Political Science 33(3):443-67.

Birch, Sarah. 2007. "Electoral Systems and Electoral Misconduct.” Comparative Political Studies 40(12), pp. 1533-56.

--- 2008. 'Electoral Institutions and Popular Confidence in Electoral Processes: A CrossNational Analysis.” Electoral Studies 27(2). 
Blais, André. 2000. To Vote to Not to Vote: The Merits and Limits of Rational Choice Theory. Pittsburgh, PA: University of Pittsburgh Press.

-- 2006. “What Affects Voter Turnout?” Annual Review of Political Science 9, pp. 111-25.

Blais, André, and R. K. Carty. 1990. "Does Proportional Representation Foster Voter Turnout?" European Journal of Political Research 18:167-81.

Blais, André, and Agnieszka Dobrzynska. 1998. "Turnout in Electoral Democracies." European Journal of Political Research 33:239-61.

Bratton, Michael. 1998. "Second Elections in Africa." Journal of Democracy 9(3).

Bratton, Michael and Nicolas van de Walle. 1997. Democratic Experiments in Africa: Regime Transitions in Comparative Perspective. Cambridge; Cambridge University Press.

Callahan, William A. 2000. Pollwatching, Elections and Civil Society in Southeast Asia. Aldershot: Ashgate.

Campbell, Angus, Philip Converse, William Miller, and Donald Stokes. 1960. The American Voter. New York: Wiley.

Clarke, Harold D. and Alan C. Alcock. 1989. "National Elections and Political Attitudes: The Case of Political Efficacy.” British Journal of Political Science 19(4):551-62.

Clarke, Harold D., David Sanders, Marianne C. Stewart and Paul Whiteley. 2004. Political Choice in Britain. Oxford: Oxford University Press.

Cox, Gary W., and J. Morgan Kousser. 1981. "Turnout and Rural Corruption: New York as a Test Case.” American Journal of Political Science 25(4):646-63.

Crewe, Ivor. 1981. "Electoral Participation." In Democracy at the Polls: A Comparative Study of Competitive National Elections, eds. David Butler, Howard R. Penniman and Austin Ranney. Washington, DC and London: American Enterprise Institute, pp. 216-63. 
Dalton, Russell J. 1996. Citizen Politics: Public Opinion and Political Parties in Advanced Industrial Democracies, $2^{\text {nd }}$ ed. Chatham, NJ: Chatham House.

Derbyshire, J., and Ian Derbyshire. 1996. Political Systems of the World. Oxford: Helicon.

Desposato, Scott W. “How Does Vote Buying Shape the Legislative Arena?” In Frederic Charles Schaffer (ed.). Elections for Sale: The Causes and Consequences of Vote Buying. Boulder and London, Lynne Rienner, pp. 101-22.

Elklit, Jørgen. 1999. "Electoral Institutional Change and Democratization: You Can Lead a Horse to Water, But You Can't Make it Drink." Democratization 6(4):28-51.

Elklit, Jørgen, and Andrew Reynolds. 2002. "The Impact of Election Administration on the Legitimacy of Emerging Democracies." Commonwealth and Comparative Politics 40(2): 86-119.

--- 2005. “A Framework for the Systematic Study of Election Quality.” Democratization 12(2):147-62.

Ferejohn, John A., and Morris P. Fiorina. 1974. "The Paradox of Not Voting: A Decision Theoretic Analysis.” American Political Science Review 68:525-36.

Festinger, Leon. 1957. A Theory of Cognitive Dissonance. Stanford, CA: Stanford University Press.

Figueroa, Mark, and Amanda Sives. 2002. "Homogeneous Voting, Electoral Manipulation and the 'Garrison' Process in Post-Independence Jamaica." Commonwealth and Comparative Politics 40(1) (2002):81-108.

Finkel, Steven E. 1985. "Reciprocal Effects of Participation and Political Efficacy: A Panel Analysis” American Journal of Political Science 29(4):891-913.

--- 1987. “The Effects of Participation on Political Efficacy and Political Support: Evidence from a West German Panel." Journal of Politics 49(2):441-64. 
Franklin, Mark N. 1996. "Electoral Participation.” In Comparing Democracies: Elections and Voting in Global Perspective. Eds. Lawrence LeDuc, Richard G. Niemi, and Pippa Norris. Thousand Oaks, London and New Delhi: Sage, pp. 216-35.

--- 1999. 'Electoral Engineering and Cross-National Turnout Differences: What Role for Compulsory Voting?” British Journal of Political Science 29(1):25-24.

--- 2002. “The Dynamics of Electoral Participation.” In Comparing Democracies 2: New Challenges in the Study of Elections and Voting. Eds. Lawrence LeDuc, Richard G. Niemi, and Pippa Norris. London, Thousand Oaks, and New Delhi, pp. 148-66.

--- 2004. Voter Turnout and the Dynamics of Electoral Competition in Established Democracies Since 1945. Cambridge: Cambridge University Press.

Geys, Benny. 2006. "Voter Turnout: A Review of Aggregate-Level Research.” Electoral Studies 25(4), pp. 637-663.

Ginsberg, Benjamin, and Robert Weissberg. 1978. "Elections and the Mobilization of Popular Support.” American Journal f Political Science 22(1):31-55.

Goodwin-Gill, Guy S. 1998. Codes of Conduct for Elections. Geneva: Inter-Parliamentary Union.

Gray, Mark, and Miki Caul. 2000. "Declining Voter Turnout in Advanced Industrial Democracies, 1950 to 1997: The Effects of Declining Group Mobilization.” Comparative Political Studies 33(9):1091-1122.

Hartlyn, Jonathan and Jennifer McCoy. 2006. “Observer Paradoxes: How to Assess Electoral Manipulation.” In Andreas Schedler (ed). Electoral Authoritarianism: The Dynamics of Unfree Competition. Boulder and London: Lynne Rienner, pp. 41-54. 
Hicken, Allen D. "How Do Rules and Institutions Encourage Vote Buying?” In Frederic Charles Schaffer (ed.). Elections for Sale: The Causes and Consequences of Vote Buying. Boulder and London, Lynne Rienner, pp. 47-60.

International Institute for Democracy and Electoral Assistance [IDEA]. 2002. Voter Turnout since 1945: A Global Report. Stockholm: International Institute for Democracy and Electoral Assistance.

Jackman, Robert W. 1987. "Political Institutions and Voter Turnout in the Industrial Democracies.” American Political Science Review 81(2):405-23.

Jackman, Robert W., and Ross A. Miller. 1995. "Voter Turnout in the Industrial Democracies During the 1980s.” Comparative Political Studies 27(4):467-92.

Karp, Jeffrey A., and Susan A. Banducci. 2008. "Political Efficacy and Participation in Twenty Five Democracies: How Electoral Systems Shape Political Behaviour.” British Journal of Political Science 38(2).

Lassen, David Dreyer. 2005. "The Effect of Information on Voter Turnout: Evidence from a Natural Experiment.” American Journal of Political Science 49(1):103-118.

LeDuc, Lawrence, Richard G. Niemi, and Pippa Norris (eds.). 1996. Comparing Democracies: Elections and Voting in Global Perspective. Thousand Oaks, London, and New Delhi: Sage.

LeDuc, Lawrence, Richard G. Niemi, and Pippa Norris (eds.). 2002. Comparing Democracies 2: New Challenges in the Study of Elections and Voting. Thousand Oaks, London, and New Delhi: Sage.

Lehoucq, Fabrice E. 2003. “Can Parties Police Themselves? Electoral Governance and Democratization.” International Political Science Review 23(1):29-46. 
--- 2003. "Electoral Fraud: Causes, Types, and Consequences.” Annual Review of Political Science 6:233-56.

Lehoucq, Fabrice E., and Iván Molina. 2002. Stuffing the Ballot-Box: Fraud, Electoral Reform, and Democratization in Costa Rica. Cambridge: Cambridge University Press. Lyons, Terrence. 2004. "Post-Conflict Elections and the Process of Demilitarizing Politics: The Role of Electoral Administration.” Democratization 11(3):36-62.

McCann, James A., and Jorge I. Domínguez. 1998. "Mexicans React to Political Fraud and Corruption: An Assessment of Public Opinion and Voting Behavior." Electoral Studies 17(4):483-503.

Mackie, Tom. and Richard Rose. 1997. A Decade of Election Results: Updating the International Almanac. Glasgow: Centre for the Study of Public Policy, University of Strathclyde.

Milner, Henry. 2002. Civil Literacy; How Informed Citizens Make Democracy Work. Hanover, NH and London: University Press of New England.

Molina, Iván and Fabrice Edouard Lehoucq. 1999. "Political Competition and Electoral Fraud: A Latin American Case Study.” Journal of Interdisciplinary History 30(2):199234.

Mozaffar, Shaheen. 2002. "Patterns of Electoral Governance in Africa's Emerging Democracies.” International Political Science Review 23(1).

Mozaffar, Shaheen, and Andreas Schedler. 2002. 'The Comparative Study of Electoral Governance - Introduction.” International Political Science Review 23(1):5-27.

Nadeau, Richard, and André Blais. 1993. “Accepting the Election Outcome: The Effect of Participation on Losers' Consent.” British Journal of Political Science 23(4):553-63. 
Norris, Pippa. 2002. Democratic Phoenix: Reinventing Political Activism. Cambridge: Cambridge University Press.

--- 2004. Electoral Engineering: Voting Rules and Political Behaviour. Cambridge; Cambridge University Press.

Oberst, Robert C., and Amy Weilage. 1990. "Quantitative Tests of Electoral Fraud: The 1982 Sri Lankan Referendum." Corruption and Reform 5:49-62.

OSCE/ODIHR. 2001. "Republic of Belarus Presidential Election, 9 September 2001, OSCE/ODIHR Limited Election Observation Mission Final Report.” Warsaw: OSCE/ODIHR, 4 October.

Pastor, Robert A. 1999. "The Role of Electoral Administration in Democratic Transitions: Implications for Policy and Research.” Democratization 6(4):1-27.

Pérez-Liñán, Aníbal. 2001. "Neoinstitutional Accounts of Voter Turnout; Moving Beyond Industrial Democracies.” Electoral Studies 20(2):281-97.

Powell, G. Bingham Jr. 1980. "Voting Turnout in Thirty Democracies: Partisan, Legal, and Socio-Economic Influences." In Electoral Participation: A Comparative Analysis. Ed. Richard Rose. Beverly Hills and London: Sage, pp. 5-34.

--- 1982. Contemporary Democracies: Participation, Stability, and Violence. Cambridge, MA and London: Harvard University Press.

--- 1986. “American Turnout in Comparative Perspective.” American Political Science Review 80(1):17-43.

Przeworski, Adam. 1988. "Democracy as the Contingent Outcome of Conflicts." In Constitutionalism and Democracy. Eds. J. Elster and R. Slagstad. Cambridge: Cambridge University Press. 
Rasbash, Jon, Fiona Steele, William Browne, and Bob Prosser. 2004. A User's Guide to MLwiN version 2.0. London: Centre for Multilevel Modelling, Institute of Education, University of London.

Reynolds, Andrew and Ben Reilly. 1997. The International IDEA Handbook of Electoral System Design. Stockholm: International IDEA.

Reynolds, Andrew, Ben Reilly, and Andrew Ellis. 2005. Electoral System Design: The New International IDEA Handbook. Stockholm: International IDEA.

Riker, William H., and Peter C. Ordeshook. 1968. "A Theory of the Calculus of Voting." American Political Science Review 62:25-43.

Rosenstone, Steven, and Mark Hansen. 1993. Mobilization, Participation and Democracy in America. New York: Macmillan.

Schaffer, Frederic Charles. 2002. "Might Cleaning Up Elections Keep People Away from the Polls? Historical and Comparative Perspectives.” International Political Science Review 23(1):69-84.

--- 2005. "Clean Elections and the Great Unwashed: Vote Buying and Voter Education in the Philippines.” Occasional Paper No. 21, School of Social Science, Institute for Advanced Study, Princeton, NJ.

--- 2007a. "Why Study Vote Buying?.” In Frederic Charles Schaffer (ed.). Elections for Sale: The Causes and Consequences of Vote Buying. Boulder and London, Lynne Rienner, pp. $1-16$.

2007b. "Lessons Learned.” In Frederic Charles Schaffer (ed.). Elections for Sale: The Causes and Consequences of Vote Buying. Boulder and London, Lynne Rienner, pp. 183200. 
Schaffer, Frederic Charles and Andreas Schedler. 2007. "What Is Vote Buying?” In Frederic Charles Schaffer (ed.). Elections for Sale: The Causes and Consequences of Vote Buying. Boulder and London, Lynne Rienner, pp. 17-30.

Schedler, Andreas. 2002a. "Elections without Democracy: The Menu of Manipulation." Journal of Democracy 13(2).

--- 2002B. "The Nested Game of Democratization by Elections.” International Political Science Review 23(1):103-22.

Schedler, Andreas. 2006. "The Logic of Electoral Authoritarianism.” In Andreas Schedler (ed). Electoral Authoritarianism: The Dynamics of Unfree Competition. Boulder and London: Lynne Rienner, pp. 1-23.

Steenbergen, Marco R., and Bradford S. Jones. 2002. "Modeling Multilevel Data Structures.” American Journal of Political Science 46(1):218-37.

Stokes, Susan C. “Is Vote Buying Undemocratic?” In Frederic Charles Schaffer (ed.). Elections for Sale: The Causes and Consequences of Vote Buying. Boulder and London, Lynne Rienner, pp. 81-99.

Ulhaner, Carole J. 1989. “Rational Turnout: The Neglected Role of Groups.” American Journal of Political Science 33(2):390-422.

Verba, Sidney, Norman H. Nie, and Jae-on Kim. 1978. Participation and Political Equality: A Seven-Nation Comparison. Cambridge: Cambridge University Press.

Verba, Sidney, Kay Schlozman ad Henry Brady. 1995. Voice and Equality. Cambridge, MA: Harvard University Press.

Vowles, Jack. 2002. “Offsetting the PR Effect? Party Mobilization and Turnout Decline in New Zealand, 1996-99.” Party Politics 8(5):587-605. 


\section{Appendix: Data Sources and Variable Construction}

Individual-level Cross-National Data were taken from CSES Module 1; see 'Comparative Study of Electoral Systems - Module 1 (1996-2001 [sic]) Micro-District-Macro Data Codebook:

Variable Descriptions', full release, 4 August, 2003, available at www.cses.org, for full details.

Perceptions of electoral fairness (variable A3002): See above for question wording. This was constructed on an (inverted) five point scale, where 5 represents the response "last election was conducted fairly", 1 represents the response "last election was conducted unfairly", and 2, 3, and 4 are intermediate points. 'Broad confidence' was constructed as a dummy variable ( $1=1$ or 2 on the original five-point scale; $0=3,4$, or 5 ).

Turnout (A2028) was coded as a dummy variable on the basis of the relevant survey item. 'Inconsistent' responses were coded in accordance with the voter's declared participation behavior, but use of an alternative coding, in which these responses were coded as missing data, does not alter the results of the analysis substantively. 'Don't know' and 'Refused to say whether voted' were coded as missing data. Respondents under the voting age were removed.

Age (A2001) was measured in years.

Education level (A2003) was coded on an eight-point scale ranging from 1 for 'none' to 8 for 'university undergraduate degree completed'.

Socio-economic status was indicated by relative levels of household income (A2012), measured in population quintiles.

Gender (A2002) was coded as a dummy variable for female.

Union membership (A2005) was coded as a dummy variable for union members.

Frequency of religious service attendance (A2015), employed instead of expressed degree of religiosity due to greater data availability, was measured on a six-point scale ranging from 1 for 'never' to 6 for 'once a week'. 
Majority ethnic group: A dummy variable was created designating ' 1 ' if the respondent was a member of the majority ethnic group and ' 0 ' if he or she was a member of a minority group. This variable was created on the basis of three variables coded from CSES data: variables for religious, language, and ethnic groups. Religious majority group member (A2017) was coded ' 1 ' if the respondent was a member of the religious majority group in the country in question, and ' 0 ' otherwise. For the purposes of classification, protestant denominations were combined into a single category. If no religious group formed an absolute majority in the country in question, this variable was not coded. Linguistic majority group member (A2018) was coded ' 1 ' if the respondent was a member of the linguistic majority group in the country in question, and ' 0 ' otherwise. If no linguistic group formed an absolute majority in the country in question, this variable was not coded. Ethnic majority group member (A2021) was coded ' 1 ' if the respondent was a member of the ethnic majority group in the country in question, and ' 0 ' otherwise. If no ethnic group formed an absolute majority in the country in question, this variable was not coded. The composite majority group variable was coded on the basis of the three variables described above for 16 states according to data availability and functional salience. Data for all three ethnic variables were missing for the following ten cases: Denmark, Germany, Hungary, Iceland, Japan, South Korea, the Netherlands, Norway, Portugal and Switzerland. In four cases, only one of the above-described variables was generated (ethnicity in Lithuania, religion in Poland, language in Sweden and religion in the USA). For the remaining thirteen countries, a choice was made between variables on the basis of functional salience. Ethnicity was coded for in Belarus, the Czech Republic, Mexico, Romania, Russia, Slovenia, Ukraine and Great Britain. Language was coded for in Canada, Spain and Taiwan. Religion was coded for in Hong Kong and Israel. 
Party identification was coded as a dummy variable, based on replies to survey item A3004, "Are you close to any political party". 'Inconsistent' responses were coded according to the stated identification/non-identification of the respondent.

Identification with a losing party/candidate was coded in terms of the questions "Are you close to any political party?" (A3004), and "What party is that?" (A3005). Some surveys also asked about identification with party blocks (A3007). The 'party identification with a loser' variable was coded ' 1 ' if none of the parties identified by respondents was a winner, defined as a party/block that formed part of the government/coalition following the election, or, in the case of legislative elections held in presidential systems, the party that won the largest number of seats in the legislature (details of government formation were obtained from country notes in the CSES Codebook as well as from various issues of Electoral Studies). In all cases but one, the winning presidential candidate in concurrent elections was from a party coded as a winner in this way. The exception was the US, where the winning candidate was from a different party, and winners were coded according to the presidential election result. Respondents from the Belarusian and Lithuanian surveys could not be coded because the winning presidential candidates were independents.

Political knowledge was coded in terms of a correct response to the first of the three such questions included in the Module (A2023); missing data for the second and third questions precluded their use. Political knowledge was coded as a dummy variable, where ' 1 ' indicated a correct reply to the question, and '0' indicated an incorrect response or 'don't know'.

Efficacy (A3029) was coded on the basis of the question "Some people say that no matter who people vote for, it won't make a difference to what happens. Others say that who people vote for can make a difference to what happens. Using the scale on this card, (where ONE means that voting won't make a difference to what happens and FIVE means that voting can make a 
difference), where would you place yourself?’ The replies were inverted. 'Don't know' responses were coded as missing data.

Satisfaction with democracy (A3001) was constructed on the basis of the question "On the whole, are you very satisfied, fairly satisfied, not very satisfied, or not at all satisfied with the way democracy works in [country]", with "very satisfied" being coded as 4, and so on. 'Don't know' responses were coded as missing data.

\section{Election-level Cross-National Data:}

Aggregate turnout figures were taken from CSES Module I database; the International IDEA database at www.idea.int; OSCE/ODIHR, 2001; and Electoral Studies, various issues. Electoral system was measured in terms of a dummy variable indicating that the electoral process in question included a proportional representation component. Finer gauges of electoral system design were not viable, as a number of the elections in question were concurrent presidential and parliamentary contests, or presidential elections alone. This variable reflects the supposition that voters will be brought to the polls by any PR element in the system. Data on system types was taken from the CSES database, Reynolds and Reilly 1997 and Reynolds, Reilly and Ellis 2005.

Closeness of the race/margin of victory: Following Franklin $(2002 ; 2004,75)$, the closeness of the race was operationalized in terms of margin of victory as the difference in vote share between the strongest and the second strongest party (or presidential candidate). Where parliamentary and presidential elections were held simultaneously, this figure for is calculated as the average of the differences in the two different contests. Data were from the CSES Module I database, with the exception of Belarus (missing from the CSES database), which were taken from OSCE/ODIHR, 2001. 
Decisiveness: A scale was constructed in which a country was awarded one point for having a directly-elected president, one for having a bicameral legislature, and one for federalism. The resulting scale was inverted, such that high values represent decisive elections (see Blais and Dobrzynska 1998; Blais 2000:27; Franklin 2004: 124 for similar scales). Data were taken from Derbyshire and Derbyshire, 1996.

Election type was operationalized in terms of a dummy variable designating concurrent (parliamentary and presidential) elections. The Israeli election, where parliament and president were elected separately, was coded as concurrent.

Expenditure limit was constructed as a dummy variable from the International IDEA database on the funding of political parties and election campaigns, on the basis of the following question: "Is there a ceiling on party election expenditure" (IDEA, 2003, pp. 205-8). These data were supplemented by data from the Epic Project database at www.epicproject.org.

Time since last national-level election: this was entered into the models in months. Sources for this variable included the CSES Codebook notes on elections; Mackie and Rose 1997; and Electoral Studies, various issues.

Per capita GDP (logged) was employed as a measure of economic development. Data for per capita GDP (2000) were taken from the Penn World Table, Version 6.1, Center for International Comparisons at the University of Pennsylvania (CICUP), October 2002 (available at http://pwt.econ.upenn.edu/); and the National Statistics Office of the Republic of China (Taiwan) website at eng.stat.gov.tw.

Population size (logged): data on total population size (in thousands) were obtained from the UN Population Database, 2000 (available at http://esa.un.org/unpp/). Data for Taiwan were taken from the CIA World Factbook 2000. 
Experience of democracy: 'Democratic' was defined as a 'Polity' score of over 6 in the Polity IV dataset; states that had such a score for at least 15 years (minimum three election cycles) prior to the election in question were coded as established democracies. Though not included in the Polity dataset, Iceland was also included in this category. For details, see the Polity IV website at www.cidcm.umd.edu/inscr/polity/. The states coded as established democracies in this way included: Canada, Denmark, Germany, Great Britain, Iceland, Israel, Japan, the Netherlands, New Zealand, Norway, Portugal, Spain, Sweden, Switzerland and the US. This variable was coded as a dummy in order to maximise the inclusion of macro-level cases.

British data were taken from British Election Panel Study 1997-2001, housed at the UK Data Archive at www.data-archive.ac.uk.

Perceptions of electoral fairness: See above for question wording. This indicator was constructed on an (inverted) five point scale, where 5 represents the response "last election was conducted fairly", 1 represents the response "last election was conducted unfairly", and 2, 3, and 4 are intermediate points on the scale.

Turnout was coded as a dummy variable on the basis of the following survey item: "Talking to people about the general election, we have found that a lot of people didn't manage to vote. How about you, did you manage to vote in the general election?'. 'Don't know' and 'Refused' responses were coded as missing data.

Age was measured in years.

Gender was coded as a dummy variable for female.

Education was coded on a seven-point scale for highest educational qualification obtained, ranging from 1 for 'no qualification' to 7 for '[university] degree'. 
Household income was coded as a dummy variable designating income above the median band for the relevant year (£15,000-£17,999 for 1997 and $£ 20,000-£ 22,999$ for 2001$)$.

Interest in politics was coded on a five point scale based on responses to the following question: 'How much interest do you generally have in what is going on in politics? A great deal, quite a lot, some, not very much, or none at all”.

Party identification was coded as a series of four dummy variables based on responses to two survey items: "Generally speaking, do you think of yourself as Conservative, Labour, Liberal Democrat, (Nationalist/Plaid Cymru) or what?” and a follow-up question for nonidentifiers: "Do you generally think of yourself as a little closer to one of the parties than the others? IF YES: Which Party?" Variables were constructed for Labour (the winning party in both 1997 and 2001), Conservative, and other party identifiers, as well as those with no party identification. No party identification was the base category employed in the equations presented in Table 3. 


\section{Notes}

${ }^{1}$ In some formal boycotts depress turnout (Pastor, 1999), but boycotts did not play a prominent role in any of the elections included in this analysis.

${ }^{2}$ Manipulators may also use seek to demobilize the supporters of opponents, thereby decreasing turnout (Cox and Kousser 1981; Schaffer 2002; 2005; Schaffer and Schedler, 2007), though evidence suggests that this is less frequent than vote-buying. Most case studies have found electoral manipulation to be linked to inflated turnout (e.g. Akhter 2001, 203-4; Oberst and Weilage 1990; Argersinger 1985/6, 674; Shaffer 2007b, 186-7).

${ }^{3}$ Turnout levels may also in some cases be inflated through outright fraud. Yet there have been few allegations of outright fraud in the elections considered here, and most analyses carried out in this paper are based on voters' own reports of whether of not they voted.

${ }^{4}$ For full details, see the "Comparative Study of Electoral Systems - Module 1 (1996-2001 [sic]) Micro-District-Macro Data Codebook: Variable Descriptions”, full release, 4 August, 2003, available at www.cses.org. Of the 39 surveys included in Module 1, four did not ask the electoral fairness question (Australia, Belgium-Flanders, Belgium-Wallonia, Chile), and four did not include usable data for other key variables (Peru 2000, Peru 2001, Russia 2000 and Thailand). ${ }^{5}$ Some case studies have found electoral participation to be associated with higher levels of support for the government and government policy following the election (Ginsberg and Weissberg 1978; Nadeau and Blais 1993).

${ }^{6}$ This accords with studies that have found the political support and behavior of losers to differ from those of winners (e.g. Anderson and Guillory 1997; Anderson and LoTempio 2002; 
Anderson and Mendes 2006; Banducci and Karp 2003; Ginsberg and Weissberg 1978; Nadeau and Blais 1993).

${ }^{7}$ The sources for these data were LeDuc et al. 1996; LeDuc et al. 2002; the Elections and Political Transformation in Post-communist Europe database at www.essex.ac.uk/elections; and the EPIC Project database at www.epicproject.org.

${ }^{8}$ The analyses reported here were carried out using MLwiN version 2.02 software with restricted iterative generalized least squares (RIGLS) estimation, which is most appropriate with restricted numbers of level-two cases (Rasbash et al. 2004; Steenbergen and Jones 2002), and predictive quasi-likelihood (PQL) approximation for equations with discrete dependent variables. ${ }^{9}$ Following Franklin (2004), an interaction term between perceptions of electoral fairness and new electoral cohorts was included in the model (results not shown), to test possible generationspecific effects. This term was not significant, and was thus not included in the models reported. ${ }^{10}$ Membership in the majority ethnic group was included in earlier versions of this model as an alternative socio-cultural marker. This variable was insignificant, however, and it was excluded from the model presented here due to the fact that it was only available for 16 elections. ${ }^{11}$ An intermediary model with the reduced set of individual-level variables (not shown) demonstrates that misspecification resulting from the exclusion of these variables does not seriously bias the estimate for the impact of electoral confidence.

${ }^{12}$ Due to collinearity, it was not possible to include per capita GDP in the same model as established democracy. When included on its own, per capita GDP was insignificant.

${ }^{13}$ In order to facilitate the construction, estimation and interpretation of the interaction term, the measure of perceptions of electoral fairness used in this model was a dummy variable designating broad confidence in elections (scores of 1 or 2 on the original [uninverted] five-point scale). 
${ }^{14}$ The control variables included in these models were taken from the election survey in question See the Appendix for details of variable construction. 
Table 1: Confidence Elections and Rates of Electoral Participation

\begin{tabular}{|c|c|c|c|}
\hline $\begin{array}{l}\text { Country (year of } \\
\text { election) }\end{array}$ & $\begin{array}{c}\text { Aggregate Turnout } \\
(\%)^{*}\end{array}$ & $\begin{array}{c}\text { Proportion of } \\
\text { respondents with } \\
\text { full confidence in } \\
\text { the electoral process } \\
(\%) * *\end{array}$ & $\begin{array}{c}\text { Proportion of } \\
\text { respondents with } \\
\text { broad confidence in } \\
\text { the electoral process } \\
(\%) * * *\end{array}$ \\
\hline Belarus (2001) & 83.86 & 45.36 & 59.58 \\
\hline Canada (1997) & 56.20 & 34.60 & 71.42 \\
\hline Taiwan (1996) & 75.10 & 37.77 & 62.14 \\
\hline Czech Rep. (1996) & 76.70 & 46.53 & 79.79 \\
\hline Denmark (1998) & 83.10 & 88.68 & 94.87 \\
\hline Germany (1998) & 82.20 & 73.92 & 90.66 \\
\hline Great Britain (1997) & 59.40 & 56.66 & 80.55 \\
\hline Hong Kong (1998) & 53.20 & 18.14 & 56.64 \\
\hline Hong Kong (2000) & 43.50 & 17.55 & 51.21 \\
\hline Hungary (1998) & 59.90 & 59.33 & 81.89 \\
\hline Iceland (1999) & 84.70 & 59.46 & 83.89 \\
\hline Israel (1996) & 84.70 & 38.53 & 62.61 \\
\hline Japan (1996) & 59.80 & 19.29 & 42.30 \\
\hline Korea (2000) & 57.20 & 10.60 & 30.74 \\
\hline Lithuania (1997) & 50.00 & 30.57 & 55.75 \\
\hline Mexico (1997) & 54.40 & 42.67 & 56.08 \\
\hline Mexico (2000) & 63.90 & 52.38 & 67.98 \\
\hline Netherlands (1998) & 73.00 & 70.91 & 91.74 \\
\hline N. Zealand (1996) & 83.00 & 47.41 & 76.92 \\
\hline Norway (1997) & 76.80 & 81.97 & 93.16 \\
\hline Poland (1997) & 48.80 & 46.93 & 72.07 \\
\hline Portugal (2002) & 61.60 & 64.71 & 81.36 \\
\hline Romania (1996) & 78.20 & 62.24 & 81.66 \\
\hline Russia (1999) & 61.80 & 25.31 & 44.05 \\
\hline Slovenia (1996) & 75.50 & 45.47 & 67.78 \\
\hline Spain (1996) & 80.60 & 62.61 & 80.05 \\
\hline Spain (2000) & 77.30 & 55.96 & 79.73 \\
\hline Sweden (1998) & 81.40 & 75.54 & 88.02 \\
\hline Switzerland (1999) & 43.40 & 74.18 & 88.20 \\
\hline Ukraine (1998) & 68.10 & 22.84 & 37.04 \\
\hline USA (1996) & 49.00 & 49.31 & 75.35 \\
\hline Mean & 67.30 & 48.95 & 67.74 \\
\hline
\end{tabular}

* Official turnout as a proportion of the voting-age population.

** Percentage of survey respondents who answered ' 1 ' to the electoral fairness question. *** Percentage of survey respondents who answered ' 1 ' or ' 2 ' to the electoral fairness question.

See the Appendix for data sources. 
Table 2: Multilevel Logit Models of Reported Turnout

\begin{tabular}{|c|c|c|c|}
\hline Variable & Model 1 & Model 2 & Model 3 \\
\hline \multicolumn{4}{|l|}{ Fixed effects: } \\
\hline \multicolumn{4}{|l|}{ Individual-level: } \\
\hline $\begin{array}{l}\text { Perceptions of electoral } \\
\text { fairness (PEF), } 1-5\end{array}$ & $0.135 * * *(0.027)$ & $0.150 * * *(0.022)$ & \\
\hline PEF, dummy variable & & & $0.307 * * *(0.099)$ \\
\hline Age & $0.029 * * *(0.002)$ & $0.030 * * *(0.002)$ & $0.030 * * *(0.002)$ \\
\hline Gender (female) & $0.013 \quad(0.069)$ & & \\
\hline Education & $0.169 * * *(0.026)$ & $0.154 * * *(0.024)$ & $0.154 * * *(0.023)$ \\
\hline Income & $0.083 * * \quad(0.030)$ & $0.094 * * *(0.022)$ & $0.094 * * *(0.022)$ \\
\hline Union member & $0.292 * * *(0.070)$ & & \\
\hline Religious attendance & $0.116 * * *(0.029)$ & & \\
\hline Political knowledge & $0.615 * * *(0.066)$ & & \\
\hline Party identification & $0.824 * * *(0.090)$ & $0.895 * * *(0.081)$ & $0.895 * * *(0.081)$ \\
\hline Efficacy & $0.217 * * *(0.026)$ & $0.237 * * *(0.022)$ & $0.240 * * *(0.022)$ \\
\hline $\begin{array}{l}\text { Satisfaction with } \\
\text { democracy }\end{array}$ & $0.075 * * \quad(0.030)$ & $0.097 * * *(0.023)$ & $0.101 * * *(0.023)$ \\
\hline Identifies with loser & $\begin{array}{ll}0.151 & (0.239) \\
\end{array}$ & & \\
\hline $\begin{array}{l}\text { Identifies with loser } x \\
\text { PEF }\end{array}$ & $\begin{array}{ll}-0.020 & (0.062)\end{array}$ & & \\
\hline \multicolumn{4}{|l|}{ Election-level: } \\
\hline PR component & & $0.479 \quad(0.478)$ & $0.476(0.470)$ \\
\hline Margin of victory & & $0.033 * * \quad(0.014)$ & $0.033 * *(0.013)$ \\
\hline Decisiveness & & $-0.055 \quad(0.207)$ & $-0.061 \quad(0.208)$ \\
\hline Concurrent elections & & $0.729 * \quad(0.362)$ & $-0.729 \quad(0.367)$ \\
\hline Expenditure limit & & $(0.259)$ & $\begin{array}{ll}-0.069 & (0.259) \\
\end{array}$ \\
\hline Time since last election & & $(0.011)$ & $0.011 \quad(0.011)$ \\
\hline Size of population $(\log )$ & & $(0.091)$ & $-0.034 \quad(0.088)$ \\
\hline Established democracy & & $(0.268)$ & $\begin{array}{ll}-0.167 & (0.281) \\
\end{array}$ \\
\hline $\begin{array}{l}\text { Cross-level interaction } \\
\text { between PEF and est. } \\
\text { democracy }\end{array}$ & & & $0.157 \quad(0.130)$ \\
\hline Constant & $-3.252(0.423)$ & $-3.635(1.234)$ & $-3.248 \quad(1.211)$ \\
\hline \multicolumn{4}{|l|}{ Random terms: } \\
\hline Intercept variance & $0.802 * * *(0.177)$ & $0.662 * * *(0.150)$ & $0.620 * * *(0.121)$ \\
\hline PEF variance & & $(0.004)$ & $(0.026)$ \\
\hline Chi squared - fixed & 1860.861 (14df) & 1709.109 (16df) & 1882.416 (17df) \\
\hline Chi squared - random & $20.491(1 \mathrm{df})$ & $43.658(3 \mathrm{df})$ & $47.606(3 \mathrm{df})$ \\
\hline $\mathrm{N}$ : individuals & 23,712 & 35,848 & 35,848 \\
\hline $\mathrm{N}$ : elections & 22 & 29 & 29 \\
\hline
\end{tabular}

$* \mathrm{p}<.05 ; * * \mathrm{p}<.01 ; * * * \mathrm{p}<.001 ;$ Cell entries are logit coefficients (standard errors) 
Table 3: Binary Logistic Regression Model of Turnout in Great Britain, 1997 and 2001

\begin{tabular}{|c|c|c|}
\hline Variable & 1997 & 2001 \\
\hline Perception of electoral fairness 1997 & $(0.069)$ & $0.208 * * \quad(0.075)$ \\
\hline Age & $0.025 * * *(0.005)$ & $0.022 * * *(0.005)$ \\
\hline Female gender & $0.314 * \quad(0.129)$ & $(0.142)$ \\
\hline Education & $0.051^{*}$ & $0.114 * * \quad(0.040)$ \\
\hline Household income & $(0.140)$ & $(0.157)$ \\
\hline Interest in politics & $0.477 * * *(0.071)$ & $0.535 * * *(0.078)$ \\
\hline Party identification with Labour & $1.155^{* * * *}(0.227)$ & $1.783 * * *(0.298)$ \\
\hline Party identification with Conservatives & $1.258 * * *(0.246)$ & $1.608 * * *(0.306)$ \\
\hline Party identification with other party & $1.177 * * *(0.257)$ & $1.865 * * *(0.323)$ \\
\hline Constant & $-2.823 * * *(0.420)$ & $-4.451 * * *(0.538)$ \\
\hline -2 Log Likelihood & 1630.670 & 1313.323 \\
\hline Nagelkerke $\mathrm{R}^{2}$ & 0.138 & 0.176 \\
\hline $\mathrm{N}$ & 2,478 & 1,795 \\
\hline
\end{tabular}

$* \mathrm{p}<.05 ; * * \mathrm{p}<.01 ; * * * \mathrm{p}<.001$

Cell entries are logit coefficients (standard errors) 